\title{
FIRST IMPRESSIONS AND PERCEIVED ROLES: PALESTINIAN PERCEPTIONS ON FOREIGN AID
}

\author{
BEÁTA PARAGI \\ Institute of International Studies, Corvinus University of Budapest \\ E-mail: beata.paragi@uni-corvinus.hu
}

This paper summarizes some results of a wider research on foreign aid that was conducted in the West Bank and Gaza Strip in 2010. It seeks to describe the impressions and feelings of a Palestinian aid beneficiaries as well as the roles and functions they attached to foreign aid. To capture and measure local perceptions on Western assistance a series of individual in depth interviews and few focus group interviews were conducted in the Palestinian territories. The interview transcripts were processed by content analysis. As research results show - from the perspective of aid beneficiaries foreign aid is more related to human dignity than to any economic development. All this implies that frustration with the ongoing Israeli-Palestinian conflict inevitably embraces the donor policies and practices too.

Keywords: aid beneficiaries/recipients, donor-recipient relations; foreign aid; perceptions on foreign aid

JEL-codes: ???

\section{INTRODUCTION}

When considering international aid, the views of the recipients are not taken much into account. Despite the well established tradition of domestic and international aid the overall perception of the aid endeavour are rarely focused on. This paper seeks to describe the way how a given group of aid beneficiaries, Palestinians living in the West Bank and Gaza Strip think and feel about international assistanceforeign aid received from donor countries who are members of the OECD's Development Assistance Committee (DAC) - and tries to reflect their voices and opinions. 
The international community has been supporting attempts to foster peace between the Israelis and Palestinians since the early 1990s. Palestinians have received the highest average annual official development assistance (ODA) per capita since the beginning of the Oslo Peace Process for building their system of institutions and developing their economy. Measured by ODA per capita, the peace process as well as the Palestinian national concerns seem to have been taken into consideration quite generously by the donor community:

Looking at the data presented in Table 1, it is clear that Palestinians are over-represented among the aid beneficiaries. The exceptionally high amount disbursed may imply that their views, opinion and preferences on aid are taken into account more than in any other recipient country. However, as our findings prove, this is not the case. Palestinian perceptions on foreign aid, on its role and necessity have been ignored by donor countries by and large.

\section{Related research on perceptions about foreign aid}

Even if much has been written on the objectives, roles, functions and measures of international (Western) assistance devoted to solving the Israeli-Palestinian conflict (Khadr 1999; Hooper 1999; Brynen 2000; Nakhleh 2004; Keating et al. 2005; Le More 2008), the way how the Palestinians think about and reflect on its meaning, roles and efficiency has received little attention. Only one survey conducted by the Development Studies Program at Bir Zeit University (DSP) in 2004 can be cited, results of which were summarized by Nader Said (2005). The original public opinion poll focused on the impact of international assistance as perceived by Palestinians. Building on these data and focusing on the broad concept of human security, Said concluded that "Palestinian development efforts and achievements have been destroyed by external factors" (Said 2005). Indeed, the effects of foreign aid channelled in the form of official development and humanitarian assistance has failed 'to buy peace' and has become increasingly questioned by Palestinians in the West Bank and the Gaza Strip. An opinion poll conducted by Fafo AIS in 2008 found that "[a] majority of Palestinians thought Western financial assistance to the Palestinian National Authority (PNA or PA) was doing more harm than good; two thirds (69\%) of those polled in February and March 2008 believed that aid to the PA contributed to widening the rift between Fatah and Hamas. A similar proportion (63\%) thought that aid to the PA promoted corruption. An equally significant number of respondents was convinced that aid had very little or no effect on poverty alleviation" (Fafo 2008). These findings were in tune with related Palestinian perceptions captured by other polling institutes earlier (CPRS 1999a; CPRS 1999b; CPRS 2000; Bir Zeit DSP 2004). Although Palestinian 
FIRST IMPRESSIONS AND PERCEIVED ROLES

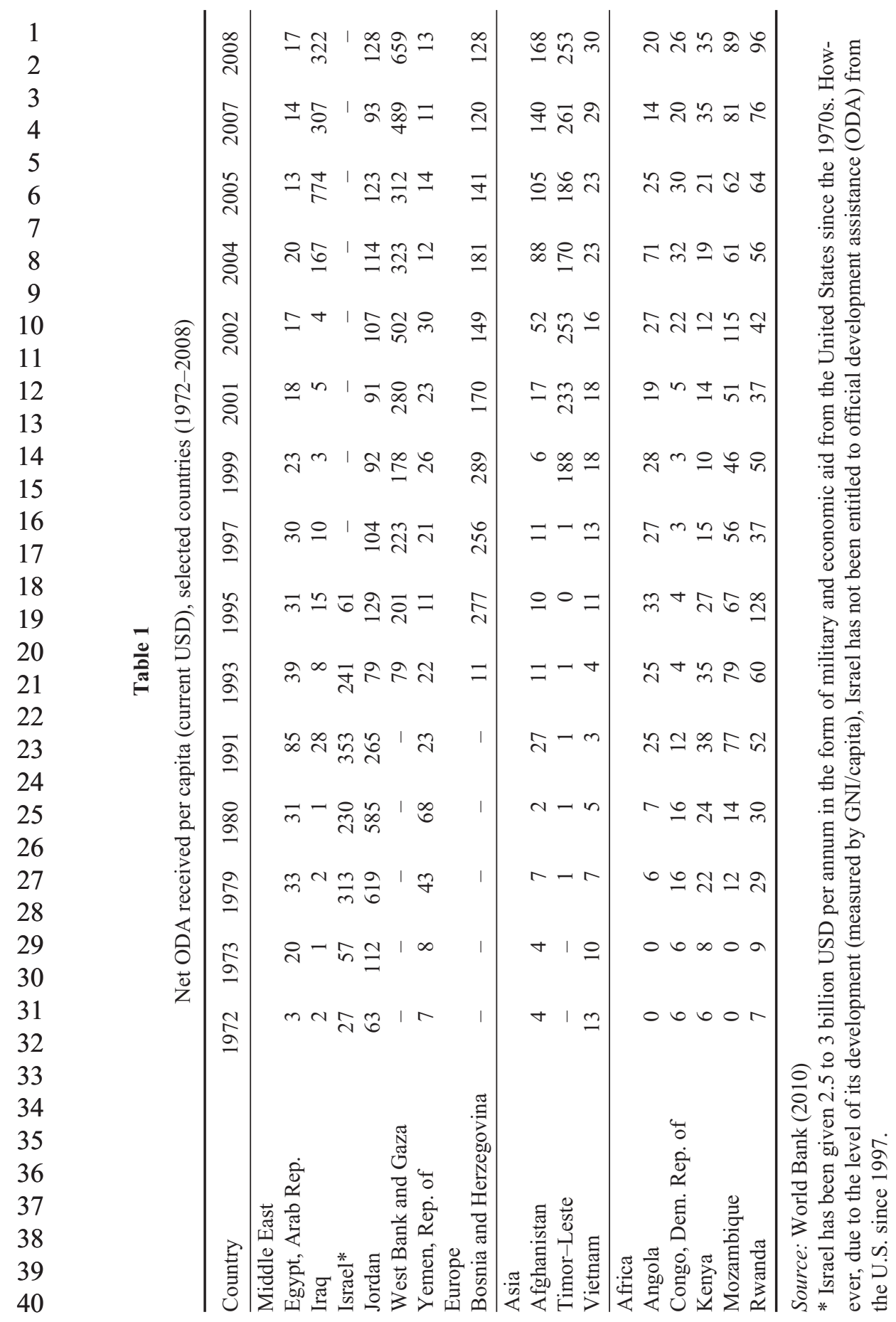


society has become increasingly suspicious of the donors' good intentions since the 1990 s, their perceptions seem to be quite heterogeneous regarding the necessity and efficiency of external help. While two thirds of Palestinians agreed that 4 foreign aid was needed because it alleviated human suffering, a similar proportion 5 felt that it also helped donors impose their national goals as well as helped Israel 6 maintain the occupation (Fafo 2010a). Since none of the referred research tried to 7 explore the concepts and notions - what foreign aid means to the Palestinian re8 cipients - it was worthwhile exploring the Palestinian mental image of foreign 9 aid.

\section{Research questions and objectives}

To learn more about the Palestinian perceptions on foreign aid, the author of this paper conducted a research in cooperation with Fafo AIS, a Norwegian research institute in 2010. The research leaned on earlier Fafo public opinion polls (Fafo 2008; Fafo 2010a; Fafo 2010b) and sought to identify sentiments and perceptions experienced by Palestinians (Paragi 2010). Core research questions included the following: How do Palestinians think about international (i.e. Western) assistance? How has the Palestinian society reached the conclusion that aid is doing more harm than good? What has formed their opinions? Does the way of thinking vary by societal characteristics and political affiliation? And last but not least, why do Palestinians in the West Bank and Gaza Strip think the way they do? To answer these questions, it was required to explore what international donor activities mean to Palestinians; what the main sources of their knowledge are; what, if any, direct, personal experiences they have (had) with international donors and foreign assistance; and how they consider the political role of international aid to the West Bank and Gaza Strip both in intra-Palestinian terms and vis-à-vis Israel. Finding answers to these questions enhanced the understanding of how Palestinians generally think about external assistance (Paragi 2010). This paper aims to summarize only the impressions and feelings exhibited by the Palestinians interviewed as well as the roles and functions they attached to foreign aid.

\section{DATA AND METHODS}

To capture and measure local perceptions on Western assistance, a series of individual in-depth interviews and a few focus group interviews were conducted in the Palestinian territories in July and August 2010. The research was partly based 
on a series of surveys and opinion polls carried out earlier by Fafo in the period of 2005 to 2010 in the West Bank and Gaza Strip. ${ }^{1}$ The questions formulated in the interview guide took into consideration the fact that the function and effects of international assistance had been quite controversial (Fafo 2008; Fafo 2010a; Fafo 2010b).

Perceptions are important because people make personal as well as community decisions based on the perceptions construed by them. Throughout the research they were understood as a kind of sensation, a way of gaining experiences by sensing the world around us (Goldstein 2009). This perceptual process is an active, but not necessarily conscious process by which individuals "gather and interpret information about the external and internal environments" and "organize and interpret their sensory impressions in order to give meaning to their environment" (Robbins 2009: 119). In other words, perception was seen as a process of attaining awareness or understanding the information sensed. It included evaluation too, even if people were not necessarily aware of the difference between their perception and reality.

Since perceptions do not necessarily comply with reality, they may be misleading, causing non-intended effects as long as they can lead to wrong decisions and choices. ${ }^{2}$ As emphasized by Fred Halliday writing on the international relations of the Middle East: "the hold of beliefs, and perceptions, on a people may [...] be the greater where the ideas in question take the form not of formal doctrines, or novel political terms, but of more everyday and unquestioned assumptions that nonetheless affect political values and choices" (Halliday 2002: 221). Equally, perceptions of international assistance contain such 'knowledge' and 'assumptions' that have been collected by Palestinians related to this issue for the past decades. Whether these perceptions comply with facts or not is secondary, at least if one accepts the notion formulated by American sociologist William I. Thomas that "if men define situations as real, they are real in their consequences" (cited by Volkart 1951: xxx). Palestinians, just as people anywhere in the world, draw conclusions and make individual, societal and political decisions in tune with their perceptions and convictions. Understanding them better is important not only for the people concerned, but to anyone being interested in the Israeli-Palestinian question.

381 See Fafo's website containing the results: http://www.fafo.no/ais/middeast/opt/index.htm

392 Note, that comparing the perceived to 'the real' was not the aim of the research. 
During the research period (2010) mainly qualitative methods were used. However, to learn more about the general sentiments regarding earlier results of international aid, quantitative interviews were also utilized. A Fafo public opinion poll containing several relevant questions was carried out in the West Bank from 9 to 15 February and in the Gaza Strip from 8 to 12 May 2010. Interviews took place at 66 fieldwork points in both areas. The respondents were randomly selected individuals aged 18 and above: 960 in the West Bank and 933 in the Gaza Strip, all interviewed face to face. ${ }^{3}$ These structured interviews were conducted in Arabic; results were published by Fafo in June 2010 (Fafo 2010a).

To explore the logic behind the general perceptions revealed by the Fafo opinion polls open-ended, more in-depth individual and group interviews were used. The qualitative research was concerned with the opinions, experiences and feelings of individual Palestinians, and its main objective was to clarify what international assistance means to members of the Palestinian society and to understand local interpretations of foreign assistance. ${ }^{4}$ Data was collected through direct encounters with Palestinian individuals. All in all 21 in-depth individual and 3 mini focus group interviews were conducted in the West Bank and Gaza Strip in July and August 2010. As far as the group interviews were concerned, three subgroups of society were approached: refugees both in the West Bank and Gaza Strip and a group of ordinary citizens in the Gaza Strip. The groups were limited to three participants (plus the moderator) in order to facilitate everyone's active participation and interaction. The interviews were conducted in Arabic. The transcripts were translated to English by the two interviewers, both of them local Fafo staff. All interviews were semi-structured containing a series of open-ended questions concentrating on three main areas: (i) basic concepts and local interpretations of international assistance; (ii) past and present experiences with foreign aid and future expectations regarding its role and impact; and (iii) the perceived priorities of Western foreign assistance with reference to the Israeli-Palestinian conflict. The interviewers both in the West Bank and in the Gaza Strip had the opportunity to engage the respondents in an 'informal' conversation as well as to urge them to elaborate on their original response in order to encourage them to reflect further on the question or topic at hand.

4 While the term 'foreign aid' covers military, humanitarian as well development assistance in general sense, it was used as an equivalent of international assistance or development aid (or that of official development assistance, ODA) during the interviews as well as upon presenting the results. The applied Arabic equivalent was al-musaadat al-dawlia (المساعدات الدولية). 
To the qualitative interviews we sought to recruit people with knowledge of 2 and interest in international assistance. The respondents were all men between 30 3 and 60 years of age (mean age close to 50). Their places of living (and that of 4 work) were Ramallah, Bethlehem and Gaza City. All of them had some solid ex5 perience with the dynamics of foreign assistance channelled to the West Bank and 6 Gaza Strip. For additional information indicative of their professional back7 ground and experience with foreign aid, see Table $2 .^{5}$

Table 2

Respondents of qualitative interviews

\begin{tabular}{lcc}
\hline & West Bank & Gaza Strip \\
\hline Senior PNA employee & 2 & 1 \\
Business people/owners & 2 & 1 \\
Academics & 3 & 2 \\
Local NGO leaders / NGO employees & 2 & 1 \\
International NGO leaders / staff & 2 & - \\
Hamula heads, tribal judges & 1 & 2 \\
Ordinary people & - & Group of 3 \\
Refugees living in camps & Group of 3 & Group of 3 \\
Refugee camp head & 1 & 14 \\
\hline Total & 16 & 1 \\
\hline
\end{tabular}

To facilitate smooth interviews, the respondents' political affiliation or voting preferences were not recorded, but the recruiting process aimed at finding respondents with political leanings reflecting the diversity of the Palestinian political scene. Answers were collected through face-to-face interviews during which the interviewers did their outmost to create a relaxed and comfortable atmosphere. However, since the conversations were recorded and notes taken, on one occasion an interviewee felt a bit uneasy and was hesitant to express his real thoughts. Apart from this one experience, the respondents were quite responsive, and some even eager, to share their opinions with us and discuss the given subject.

\section{Sources of the respondent's knowledge}

While it varied with their background and professional and institutional affiliation, the Palestinian respondents relied mainly on the following sources of information for knowledge on foreign aid: donor websites as well as that of the PNA (2010). 
1 Ministry of Planning, local media, TV stations and news papers; annual reports of

2 foundations and NGOs; workshops and lectures; ministries and information from

3 cabinet meetings. It was noticed by many that international donors raised signs

4 (billboards) at the venues of projects that they sponsored: "if the EU [or any other

5 donor] were to fund the building of a school they would announce it in the local

6 media outlets. They would also normally place signs that hold the donors' names

7 and mention the institutions that worked on the project". Civil society organiza-

8 tions and public employees were also mentioned during the interviews. Although

9 the picture in the West Bank and Gaza Strip was comparable, it was remarked that

10 "in Gaza we suffer from a critical shortage of reliable data and information. In the

11 past, we could get information from the Central Bureau of Statistics. But today the

12 Bureau is shut down because of the political situation, leaving us without this im-

13 portant [source of] information." Books and scientific publications were rarely

14 mentioned, if at all, but their main messages and conclusions were known to re-

15 spondents being familiar with academic work on international assistance to the

16 Palestinians.

17

18

19

20

21

\subsection{Data analysis}

The available data was processed by means of simple statistical analysis (quantitative interviews) as well as by analyzing the content of the qualitative interviews. The poll results were used to explore general Palestinian experiences with international assistance, and especially to examine how geographical factors, political affiliation and other factors influence people's opinions on foreign aid (Fafo 2010a).

The transcripts of individual and group interviews were processed by the means of manual content analysis (Hancock 1998, 2002; Babbie 2010: 333-343). After the relevant statements of the interview transcripts had been listed and their meaning had been determined, the data were sorted into the major and minor categories depicted in Table 3 in order to identify the structure of international assistance as understood by Palestinians.

Having read the interview transcripts, three main groups and subgroups of opinions could be identified by coding and classification of the qualitative data, i.e. the thoughts recorded by the interviewers (Table 3). The categories and codes in the Table reflect the mental image of international assistance as perceived by the Palestinians - at least by those we interviewed.

This paper contains the results gained by summarizing and analyzing qualitative data with reference to the basic concepts and local interpretations of interna- 
Table 3

Major and minor categories applied during the content analysis

\begin{tabular}{|c|c|c|}
\hline $\begin{array}{l}\text { 1. Basic concepts and } \\
\text { local interpretations* }\end{array}$ & $\begin{array}{l}\text { The meaning of the concept of } \\
\text { international assistance (IA) }\end{array}$ & $\begin{array}{l}\text { Roles and functions } \\
\text { Impressions and feelings }\end{array}$ \\
\hline & $\begin{array}{l}\text { The roles and functions of IA } \\
\text { Eras of IA } \\
\text { General features of Western assistance }\end{array}$ & \\
\hline 2. Quality of aid & $\begin{array}{l}\text { Personal experiences with assistance } \\
\text { 'Domestic' or 'indigenous' assistance } \\
\text { Assessment of PNA aid } \\
\text { Assessment of UNRWA aid }\end{array}$ & $\begin{array}{l}\text { Various forms } \\
\text { Comparison with IA } \\
\text { Infrastructure } \\
\text { Public services } \\
\text { Political role and future } \\
\text { Public services } \\
\text { Food aid }\end{array}$ \\
\hline 3. Politics of aid & $\begin{array}{l}\text { Dependency } \\
\text { Interest in maintaining the status quo }\end{array}$ & $\begin{array}{l}\text { On the donor's agenda } \\
\text { On Israeli policies }\end{array}$ \\
\hline & Intra-Palestinian relations and IA & $\begin{array}{l}\text { Palestinian responsibility } \\
\text { Legitimacy of the recipients } \\
\text { Fayyad-government (and IA) } \\
\text { Haniye-government (and IA) }\end{array}$ \\
\hline & Israeli-Palestinian relations and IA & $\begin{array}{l}\text { Dependency } \\
\text { Maintaining the occupation } \\
\text { The future of the West Bank } \\
\text { and Gaza Strip }\end{array}$ \\
\hline & Donor-Palestinian relations and IA & $\begin{array}{l}\text { Conditionality** } \\
\text { Priorities of Western foreign } \\
\text { assistance } \\
\text { Relationship and coordina- } \\
\text { tion among the concerned } \\
\text { actors }\end{array}$ \\
\hline
\end{tabular}

* This paper deals only with categories marked in bold.

** On conditionality see: Paragi (2012).

tional assistance. The profession or the institutional affiliation, just as any other characteristics of the respondents, are displayed in those cases in which the given opinion could be explained somehow by the interviewees' personal 'conduct'. Inverted commas mark the exact wording and the most apt formulation chosen from the recorded responses. 
3 Members of the international community - understood as the Western countries, 4 OECD DAC (and non-DAC) donors providing development and humanitarian 5 aid to Palestinians - were considered to be active participants in the Israeli-Pales6 tinian conflict by putting conditions on aid to one side only, namely the Palestin7 ian side. Setting conditions may have aimed at improving the Palestinian institu8 tional capacity to absorb foreign aid and complying with the developments of the 9 Israeli-Palestinian peace negotiations since 2003. However, it was more often un10 derstood as an expression of foreign political self-interest. The donors' support to 11 the peace process was primarily perceived as something which aimed at being vis12 ible and asserting their own interests, let this interest mean altruistic support for a 13 just cause or a less altruistic move to achieve foreign policy goals. The frustration 14 and hopelessness experienced by the Palestinians were direct results of the slow 15 (if any) progress on the Israeli-Palestinian negotiations about a Palestinian state. 16 Under the given political circumstances international assistance was considered 17 to be a mechanism supporting the Israeli occupation and oppression instead 18 of representing real political will of the donor countries aiming at changing the 19 status quo.

Palestinians respondents were asked to name what (first) comes to their mind upon hearing the term 'international assistance' (foreign aid). What feelings and thoughts have become attached to the term throughout the years, and what does it evoke today? The answers were grouped under two main headings. While the section titled 'impressions and feelings' seeks to embrace and present all those emotional expressions and sentiments that were associated with 'foreign aid' (section 3.1.), the section labelled 'roles and functions' contains perceptions on foreign aid, i.e. how it was interpreted and perceived to intervene and interfere in Palestinian domestic affairs (section 3.2.).

\subsection{Impressions and feelings}

Both quantitative interviews (Fafo 2010a) and qualitative surveys (Fafo 2010b; Paragi 2010) sought to capture the immediate feelings and first reactions of the people to the term 'international assistance'. Palestinians interviewed during the public opinion poll were asked to decide whether they agreed (or not) with any of the four statements formulated in Table 4.

As Table 4 shows, nearly two thirds of the respondents agreed with the statement that foreign aid was a form of compensation from those countries that could be held responsible for the situation. An equal proportion of Palestinian adults 
FIRST IMPRESSIONS AND PERCEIVED ROLES

Table 4

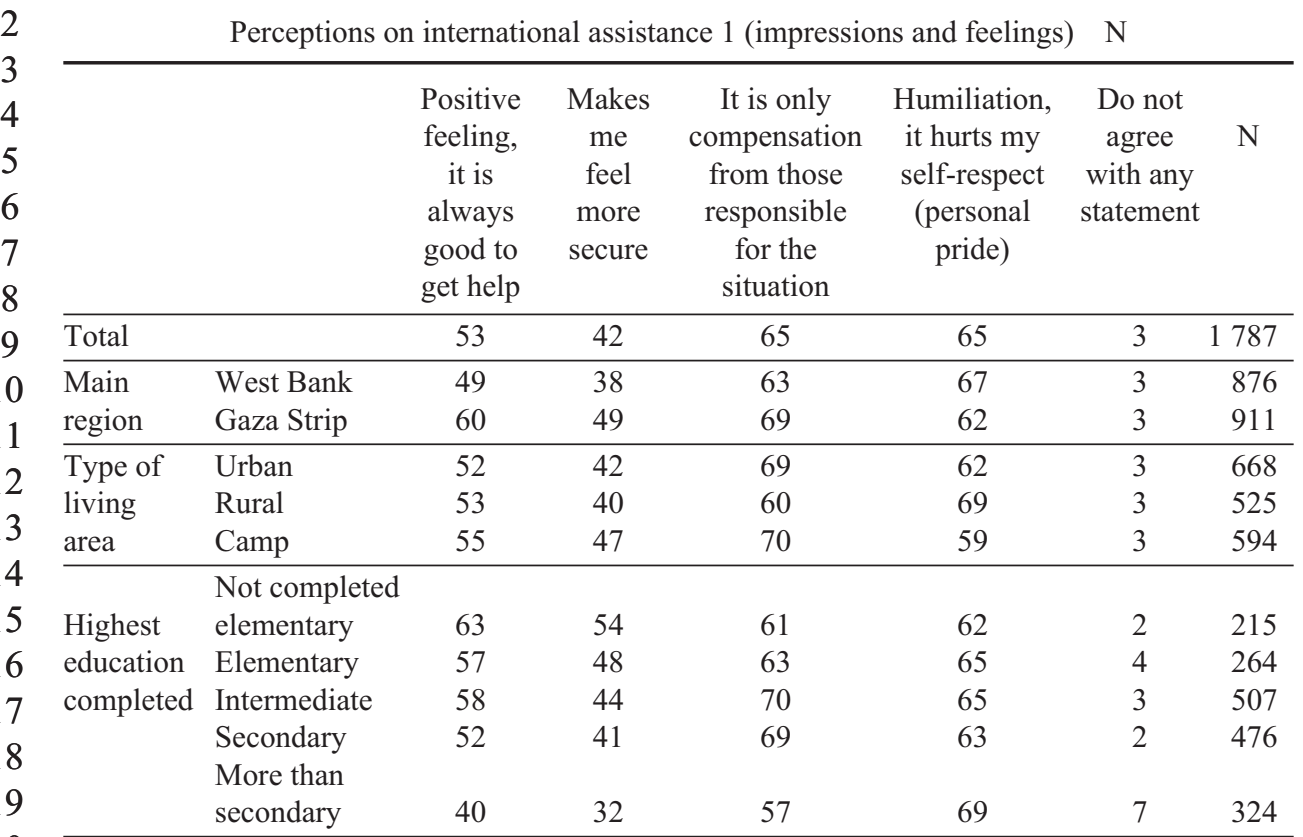

Percent of respondents 18 years and above that agree with the statement.

Source: Fafo (2010a: Table 1.3)

considered it humiliating, something that hurts their sense of pride and worth. Overall, the data did not identify any population group with feelings that deviated significantly from others, on average. Yet, place of residence, educational attainment and economic standing have moderate impact on some aspects of the people's perception. While receiving foreign aid was appreciated by $53 \%$ of the Palestinian population as 'it is always good to get help', a higher proportion of the inhabitants of the Gaza Strip held this opinion (60\%) than those of the West Bank (49\%). Four in ten respondents agreed that aid 'makes me feel more secure'. A higher proportion of people with limited schooling than among the well-educated, and who considered themselves among the poor rather than the well-to-do welcomed international assistance as something they felt good about, and which instilled a sense of security.

Completing the picture, qualitative data gained from the semi-structured interviews revealed that international assistance evoked reactions that could be labeled thus: (i) feeling of being a victim, (ii) beggar mentality, (iii) hypocrisy, and (iv) interstate power relations.

The sense of victimhood was of two sorts: Palestinians either looked at themselves as victims of the victim (the Jews) or that of the whole world. As far as the 
latter is concerned they felt to be "the [direct] victims of Europe that attempted to rid itself from the Jews in World War II. Anything that the EU gives us is the minimum compensation for the injustice they have imposed upon us." 6

Albeit in an indirect way the former approach referred to the Western responsibility too. Making the Palestinians the victim of the victim was perceived to be "the policy of the West. [Palestinians and Israelis] are both the victims of the West". With reference to this 'victimhood', some Palestinians even acknowledged that the large amount of aid channeled to the them was directly related to the fact that the 'Jewish question' - composed of the Jewish intellectual contribution to the Western civilization on the one hand and the simultaneous problem of anti-Semitism on the other one - was exceptionally important in the Western world. As one respondent put it: "They [the Jews/Israelis] have such influence that cannot be denied in the world. Fortunately or not very much so, this gets us a lot of attention that we would not get otherwise. This makes the Palestinian-Israeli conflict a more popular destination for aid.",7

Respondents expressed tangible bitterness over the fact that Palestinian society was turned into a society of beggars, since aid 'created the culture of asking for money', which 'made us weaker'. Self-critical voices, especially in Gaza, went even further saying that "the people in Gaza receive some sort of aid and they don't want to work [...] They go from one organization to the next looking for aid, applying for aid even though they are capable of working. Although job opportunities remain limited/scarce, the situation is better now [August 2010] than before. I think these people could get jobs, which even if not lucrative are better than begging for aid." 8

The notion of hypocrisy was closely related to people's perception of the 'games of politics'. As long as the "US and the other donors cannot and do not change the politics, that is their support to Israel, [so] they give the Palestinians money [instead]". As it was put bluntly by a respondent in the West Bank: "[i]f we were to ask the donors to boycott the Israeli government because it contains a figure as radical as Avigdor Liebermann, they [the donors and Israel] would riot". Our respondent regarded the donors as hypocritical actors of the political game, inasmuch as these countries have been aware of the 'facts on the ground' for decades. As it was also remarked during discussions with Palestinian politicians that escorted a public opinion poll last year (Fafo 2010b: 7), "[w]e are bored and tired of writing reports to the international community; they know everything, perhaps better than us, but what do you do? Why do you come here but do nothing?",

37 
It was also very clear that many Palestinians objected to the way Western governments have been dealing with the region in general. On the one hand, they disliked the democratic West for cooperating with less democratic regimes preying on their own people: "[t]he mistake of the US and the Europeans is that they cooperate with corrupt dictatorships. If you look at the neighboring Arab states, this is the case. They are not democratic, and the West supports them." ${ }^{10}$ On the other hand all this made some part of the Arabic public opinion including the Palestinians, who detest the West because they feel oppressed as well as being taken advantage of by their own fellows: "donors made [the Palestinians] hate the PNA [...] because they made corruption easy when they did not ask for feedback [any report on the money spent] until 2004. Additionally, any money that is given to the security forces is a form of corruption, since it is targeted against the [Palestinian] people." 11

The people's initial statements on 'foreign aid' were rarely formulated in a positive manner. It was only in the Gaza Strip that respondents attributed constructive functions to external assistance, emphasizing that it could play a significant role in assisting those living there.

\subsection{Roles and functions of foreign aid}

The 2010 poll showed that half of society $-51 \%$ of the respondents in the West Bank and $49 \%$ of those living in the Gaza Strip - thought that foreign aid buttressed the Palestinian case (Table 5). While a majority (79\%) was convinced that it alleviated human suffering, many respondents $(63 \%)$ also agreed that it made the burden of corruption easier to bear. These positive functions or effects of aid were shaded by the fact that two thirds of the respondents considered international assistance as a tool helping the donor countries impose their own policies/political objectives. Furthermore, nearly as many (61\%) thought that foreign aid to the Palestinians was in effect making it easier for Israel to sustain the occupation.

Answers were to some extent determined by political affiliation. Pro-Fatah respondents were less critical than Hamas-voters regarding the potential roles played by foreign aid. While $56 \%$ of those who said they would vote for Fatah appreciated international (Western) assistance because it benefits the Palestinian cause, only $40 \%$ of those favoring Hamas did so. Similarly, while $66 \%$ of the potential Fatah-voters felt that 'foreign aid helps the county in bearing the burden of corruption', while $59 \%$ of those affiliated with Hamas agreed with this statement.

3910 Note that the interviews took place half a year before the 'Arab Spring'.

4011 Interview with a community leader in a refugee camp, Betlehem, July 28, 2010. 


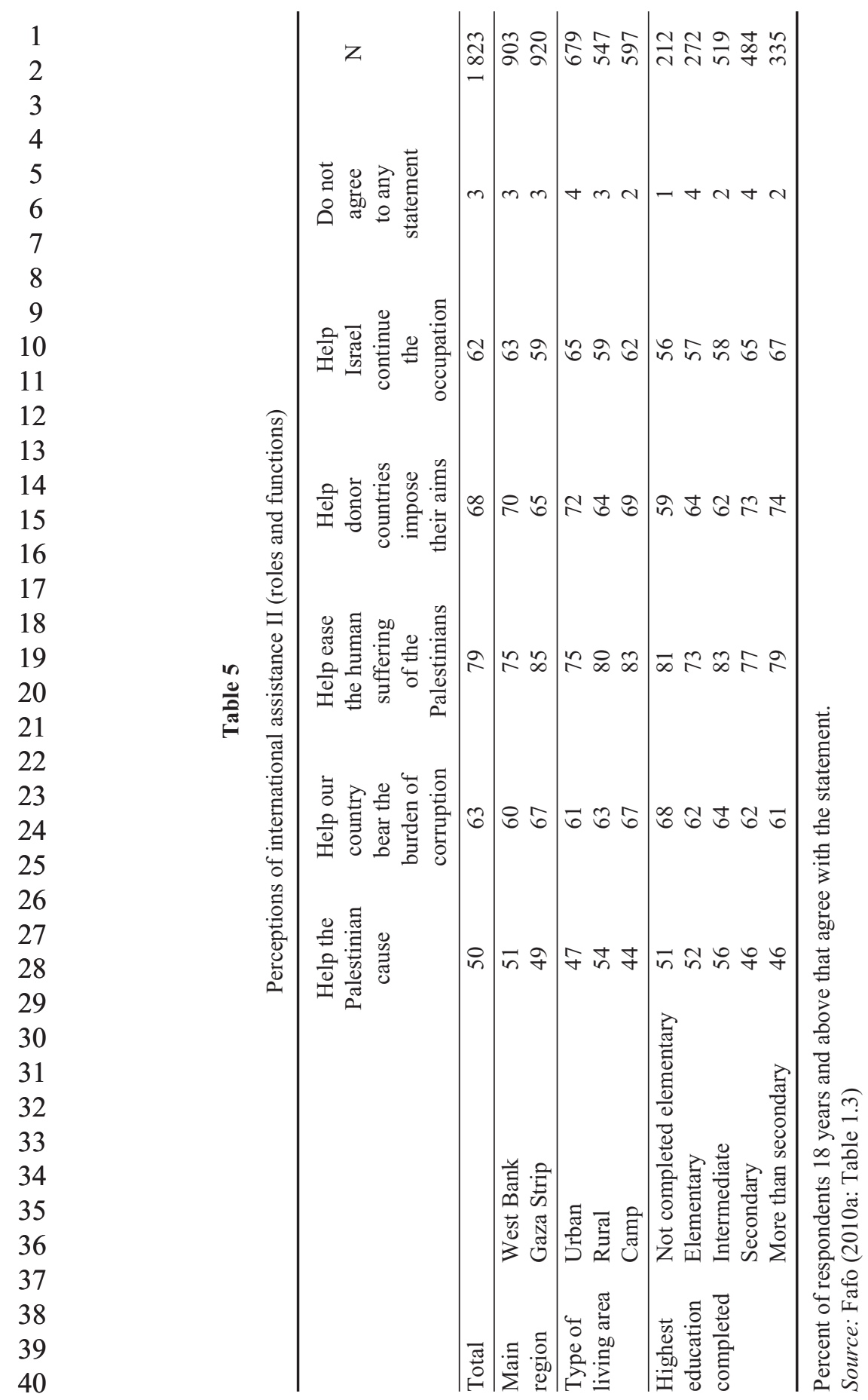


1 On some of the other items the gap between Fatah and Hamas followers was also

2 about 10 percentage points. For example, $74 \%$ of those who would vote for 3 Hamas 'if elections were held now' were convinced that foreign aid served the 4 policies of donors, $65 \%$ of Fatah-sympathizers held the same opinion. People with 5 relatively better economic conditions and higher education showed a weak ten6 dency to be more critical than other Palestinians, but the general picture is one 7 where the difference in perceptions across groups is statistically insignificant. The 8 poll did not find variation across gender and age groups (not shown here) either.

9 The qualitative interviews confirmed some of the findings of the poll but found 10 that Palestinians attributed additional functions to foreign aid too. Foreign aid was 11 seen as (i) external help easing sufferings, (ii) a way of control, (iii) a means to 12 achieve certain related and various distant political goals, (iv) a reward for good 13 performance, (v) compensation deserved by Palestinians, and (vi) a means to maintain the Israeli occupation (see this last function later).

Foreign aid was considered to be help mostly in Gaza where respondents deemed external assistance to be in accordance with their officially declared goals. According to the Gazans, international assistance aimed to improve the life of Palestinians and to develop the capacities of Palestinian society in social, health and educational terms; it aimed at enabling the PNA to pay salaries to its employees, to build roads, hospitals and schools. According to these perceptions, international assistance included all activities aimed at economic development and at helping people escape poverty.

There were similar views captured by the interviews in the West Bank, but respondents there interpreted aid seen as help more critically. Unlike in Gaza, foreign aid was considered to be a sort of medicine which could "treat the symptoms, but [not] cure the disease". Aid was mere charity providing physical survival, while "aid organizations are only saving [the Palestinians] from death while not allowing [them] to prosper". The difference between the two approaches lied in the evaluation of its effects and efficiency. While foreign aid could make a difference to people in the Gaza Strip by rebuilding what had been visibly destroyed by Israel, it could not remove the main barriers to progress in the West Bank. The structure of the occupation, the classification of the West Bank into zones A, B, C, could never be challenged by foreign aid, as it was echoed by Palestinian opinions.

Interviews suggested that it was quite common to see foreign aid as the simplest way to control Palestinian national aspirations, which served both the donors' interests and those of Israel. This control function equally had positive and negative interpretation. To some extent foreign aid was not even considered as aid: as stated by one respondent: "I don't think of it as aid. I think that this is the 
1 world's duty towards the establishment of the Palestinian state. This is reality and 2 it is not charity." 12

According to a respondent living in the West Bank, development and humanitarian aid were equally used "to control and subdue [the Palestinians]" inasmuch as "donors control every aspect of [their] lives". It was even more interesting that others looked at international assistance as something comparable to Israeli and Western notions on the objective and function of Palestinian economic development. ${ }^{13}$ As long as the Palestinians are "happy and rich", they do not become suicide bombers, which way of thinking "makes [the donors] really, dangerously in line with Israel". In the view of the respondents, international aid served Israeli interests as long as it contributed significantly to cover Palestinian needs and exempted Israel from fulfilling its duties as the occupier.

Foreign aid was widely seen by respondents both in the Gaza Strip and West Bank as a method "to pressure the PNA" to accept certain things which hurt Palestinian national aspirations and help Israel. A related popular term was the 'bargaining chip', according to which: "the donations stop [...] whenever political pressure needs to be put on the [Palestinian] government". ${ }^{14}$

Donor countries have never tried to influence Israeli policies since it has always been much simpler to "pressure the PNA" by providing assistance to it, people thought. Steps of political progress vis-à-vis Israel were seen as proof that the PNA-government led by Salam Fayyad and president Mahmoud Abbas had been forced to move ahead by foreign aid.

Others looked at aid as a means to achieve various, occasionally non-related donor goals mainly in West Bank. Visibility was widely perceived as vanity, a

12 Interview with a businessman, Bethlehem, August 17, 2010.

13 The Oslo Accords were based on a traditionally Western way of thinking, on the importance of economic utility and rationality in human decisions. The interim period and the gradual transfer of powers were expected (supposed) to provide a proper background for Palestinians to moderate their political stance due to experiencing meaningful improvement in their daily lives. Initiatives since Camp David (1978) have been built on the assumption that "happy Palestinians with jobs and steady income from employment $[\ldots]$ and with a functioning administrative structure at the local level, would be willing to negotiate for political settlement, even under occupation" (Nakhleh 2004: 178; Ben-Ami 2006: 317). The original words of the Preamble of the first Camp David Framework for Peace demonstrate this view "[p]eace requires respect for the sovereignty, territorial integrity and political independence of every state in the area [...]. Progress toward that goal can accelerate movement toward a new era of reconciliation in the Middle East marked by cooperation in promoting economic development, in maintaining stability and in assuring security" (quoted in Laqueur and Rubin 2001). The same conviction seemed to have been adopted by the PLO/Fatah upon negotiating and signing the DoP as well as promoted by the international (Western) donor community.

14 Interview with a senior member of the Palestinian Legislative Council, Bethlehem, August 7, 2010. 
sort of desire that recipients "could read the name of the donating country on the bottom of the medicine boxes". There are "many countries that want the publicity/visibility more than the real work" that should be done in order to assist the Palestinians. Some [donor countries, organizations], said one of the respondents, just want to achieve something on their own to claim all the credit "in order to satisfy their funders [at home] and convince them of success to get additional donations". Palestinians asserted that certain donors (official agencies or NGOs) exert great efforts only "to satisfy certain internal and/or external pressures from their respective governments to donate". As mirrored by Palestinian perceptions being in the aid business could be interpreted as a kind of vanity on the donor side.

Foreign aid was widely perceived as a sort of reward or a kind of compensation. While the difference is a matter of definition, the essence was that Palestinian efforts, contributions or 'sacrifices' were rightfully acknowledged by Western countries and followed up with assistance. In the words of a respondent in Gaza, it is a reward since "international aid is given to [those Palestinians] that agreed to the negotiations". In this sense, Palestinians were given aid because they (except for Hamas and smaller political movements) behaved well and adjusted to Western policies.

The idea of compensation was very close to the 'reward' notion. Palestinians made huge sacrifices in the past, which were recognized and compensated for in the present. These sacrifices were manifold. According to our respondents, donors either paid for their historical mistakes (for example the UK for the Balfour Declaration, the UN for the Partition Plan) or for not having confronted Israel for decades: "the US has to compensate us for supporting the bully and hurting us in this matter; most Europeans cannot fight Israel politically". ${ }^{15}$

Since "fighting Israel in public is political and professional suicide", the US and the other donors were paying the bill. Even if "[t]hey feel bad about the situation, they will not change their policies. They cannot but support Israel, so they give the Palestinians money to offset Israeli wrongdoings. Foreign aid cannot but finance the occupation as long as donors pay [a sort of restitution] for the damages caused by Israeli citizens or by the army."16 32 Historical experiences with Western countries made up an integral part of the 34 powers, but happen to be members of the developed world - were held responsi35 ble for the Middle East crises. Acknowledging their responsibility on the one hand 36 and led by their nation-state interests on the other, the West has been providing aid 37 to the Palestinian people for more than six decades.

3915 Interview with the director of a research centre, Bethlehem, August 2, 2010.

$40 \quad 16$ Interview, ??? kivel??? 
3 While the initial research aimed at identifying the sentiments and perceptions ex4 perienced by the Palestinians (Paragi 2010), this paper only attempted to reflect 5 the most important impressions and feelings attached to foreign aid as well as its 6 perceived roles and functions. The main questions of the research were: how do 7 Palestinians think about international, understood as Western, assistance and why 8 Palestinians think the way they do. To identify the main trends both quantitative 9 and qualitative methods were used. The form of interviews was chosen because 10 they offered the simplest way to understand what and how people think abut this 11 specific issue. While the method of public opinion poll was quite strict regarding 12 the formulation of questions as well as the opinions for responses (Fafo 2010a), 13 the qualitative interviews offered more flexibility to explore the structure of Pal14 estinian perceptions on international assistance (Fafo 2010b; Paragi 2010). Re15 lated to the results of the qualitative interviews, two general features should be mentioned. First, even if some original or authentic thoughts could be discovered upon analyzing the data, most of the recorded arguments recalled what could be read in the scientific literature and newspaper articles. Second, it must also be acknowledged that most of the respondents were not familiar with facts. They could recognize and identify the general trends, but particular details of the policies and implementation of international assistance were not known to the majority.

Impressions and sentiments as well as roles and functions of foreign aid as perceived by the recipient were among the novel findings of the research. It must be emphasized that Palestinians were at a loss to explain and assess the advantages and disadvantages of foreign aid. On the one hand it was emphasized that Palestinians were simply forced to betray their most important national goals and dreams by accepting foreign aid. Access to Western aid was seen as conditional on their 'unconditional' support for the overall goal, namely the Oslo peace process and a two-state solution. As long as Palestinian recipients shared the donors' norms and values and/or their understanding of peace process, they received aid. When compliance with Western conditions was refused, as the case of Hamas proved, access to aid was denied. Due to this conditionality, foreign aid was perceived to bolster the intra-Palestinian conflict between Hamas and Fatah. On the other hand they did not really know what else to expect from the donors except receiving more aid. Although foreign aid officially aimed at supporting the peace process, it was perceived widely as a means for maintaining in practice what should be eliminated in principle, namely the Israeli occupation. Since donors were perceived as being aware of it, Palestinians could not but conclude that Western donors provided foreign aid either for realizing alternative political goals or for their conscience's sake. 
1

2

\section{Most important terms and concepts}

Many in Palestine thought that the Palestinians have become the "victim of the victims' since World War II and argued that the 'West pays', because 'it must pay' for this situation. Since the donors did not try to tackle the real roots of the problem by political means, they were looked upon as 'hypocrite' players. Many respondents expressed frustration over external aid that only "financed and prolonged the occupation". They argued that Western aid combined with ongoing Israeli occupation just made Palestine highly "dependent on external sources" not only raising Palestinian defencelessness, but also facilitating the import of goods and services into the Palestinian territories. Palestinians could not but spend their salaries (covered by foreign aid) on products imported from and via Israel in absence of proper alternatives. However, it was rarely taken into consideration that any, even the huge Palestinian import surplus could be financed by three main sources: foreign loans, private investment and, as the Palestinian case also shows, unilateral transfers - donations.

While our respondents acknowledged that the West, honestly or not so honestly, was trying to help the Palestinian people build a state, the 'conditions' attached to foreign aid were understood as a means for "controlling the Palestinian aspirations" by "creating dependency" (Paragi 2012). And, according to the respondents, even if the donors will keep providing aid to the Palestinians in the future, none of the main problems such as the Israeli-Palestinian conflict and the Palestinian disunity will be easier to solve by accepting foreign aid.

\section{Geographical differences of perceptions}

The results revealed some interesting variation in the way of thinking between those living in the Gaza Strip and the West Bank. International assistance was perceived in a much more positive manner in the Gaza Strip. West Bankers were more outspoken when talking about foreign aid and its (political) (side)effects. Hardships and constrained access to information made respondents more cautious in formulating their thoughts in Gaza, where foreign aid was perceived to be a necessity and was seen as a good thing, a sort of help and support. Respondents in Ramallah and Bethlehem were much more concerned with criticizing the policy and practice of foreign aid. Here, the 'official' or 'nominal' function of aid, namely help, was barely mentioned. International assistance was seen to be more just and more effective than any domestic form of assistance. In the Gaza Strip, it was considered less selective in terms of political preferences than indigenous assistance. Respondents in the West Bank were more concerned with the political 
(peace) conditions attached to foreign aid than with the selectivity of domestic assistance. Corruption was considered to be worse in Gaza where respondents reported an increasing trend having been observed since 2007. Last but not least, while Fayyad was widely accused of "diverting people's attention from resistance to economic development by giving them international money" in the West Bank, respondents in Gaza did not see any contradiction between economic progress or prosperity on the one hand, and resistance to Israeli occupation on the other. According to Gazans they can - what is more, they should - go hand-in-hand.

As the research shows, supporting the peace process is sort of a vicious cycle. Israelis and Palestinians have been engaged in a legally obscure situation, somewhere between self-determination and occupation since 1993. As the perceptions reflect, foreign aid cannot but comply with the framework defined by the Oslo Accords, after all its overall goal has been declared as 'supporting the peace process'. All this implies that frustration with the ongoing Israeli-Palestinian conflict embraces donor policies and practices too - regardless of the fact that the effects and efficiency of foreign aid can be questioned on many other basis and in many other countries too. The main conclusion that may be drawn from reviewing Palestinian perceptions and sentiments is that foreign aid can by no means be treated as an 'independent variable'. Donors are perceived as active players being able to influence not just political or institutional processes, but hurting the collective and individual self-esteem of the recipient as well. Standing always at the 'recipient end' of the aid relationship makes the beneficiaries feel humiliated and unequal not only at the community (people, nation, nation-state) level, but as human beings too. Since foreign aid cannot be refused for various reasons, the only alternative to escape from this trap and to save 'the illusion of equality' is reciprocating somehow the aid received. It can be done by accepting the rules of the game. But complying with the conditions set by the donors implies surrender of domestic notions of 'justice' and 'national aspirations', which can lead to further deterioration in collective and individual self-esteem - as perceived by our respondents.

30

31

\section{REFERENCES}

Abdel-Karim, N. (2004): The Role of International Funding in Society Building and Empowerment of the Palestinian People. In: Bir Zeit: Palestine. Human Development Report. Ramallah: Bir Zeit University.

Agha, H. - Malley, R. (2009): Obama and the Middle East. New York Review of Books June 11, 2009.

Babbie, Earl (2007; 2010): The Practice of Social Science. Wadsworth CENGAGE Learning. Bir Zeit DSP (2004): An Opinion Poll Concerning the Performance of Palestinian Institutions, their Service Provision, their Role in the Development Process, and International Funding. June 4-6, 
2004. Ramallah: Bir Zeit University, http://home.Bir Zeit.edu/cds/opinionpolls/poll17/ poll17.pdf

Brynen, R. (2000): A Very Political Economy: Peacebuilding and Foreign Aid in the West Bank and Gaza. Washington: United States Institute of Peace.

Co-Sponsors Summary (1993): Summary of Co-Sponsors at the Conference to Support Middle East Peace, Washington, 1 October 1993. http:/www.mfa.gov.il/MFA/Foreign\%20Relations/ Israels\%20Foreign\%20Relations\%20since\%201947/1992-1994/114\%20Summary\%20of\%20 Co-Sponsors $\% 20$ at $\% 20$ the $\% 20$ Conference $\% 20$ to $\% 20 \mathrm{Su}$

CPRS (1999a): Public Opinion Poll 39 (2). Ramallah: CPRS, http:/www.pcpsr.org/survey/ cprspolls/99/poll39a.html\#donor

CPRS (1999b): Public Opinion Poll 43 (2). Ramallah: CPRS, http://www.pcpsr.org/survey/ cprspolls/99/poll43a.html

CPRS (2000): Public Opinion Poll 47 (2). Ramallah: CPRS, http://www.pcpsr.org/survey/ cprspolls/2000/poll47a.html\#donors

Fafo (2005): Surveying Palestinian Opinions, 2005. Opinions and Attitudes to the Peace Process, Governance, Security, and Service Provision in The West Bank and Gaza Strip. Oslo: Fafo/AIS http://www.fafo.no/ais/middeast/opt/opinionpolls/poll2005.htm

Fafo (2006): Surveying Palestinian Opinions, 2006. Satisfaction with Local Services. Oslo: Fafo/AIS, http://www.fafo.no/ais/middeast/opt/opinionpolls/palestinian_opinions_2006/ 4Satisfaction_with_local_services.pdf

Fafo (2007): Surveying Palestinian Opinions, 2007. Satisfaction with Local Services. Oslo: Fafo/AIS, http://www.fafo.no/ais/middeast/opt/opinionpolls/palestinian_opinions_2007/2007 $\% 20$ Satisfaction $\% 20$ with\%20local\%20services.pdf

Fafo (2008): Surveying Palestinian Opinions, 2008. Services and Satisfaction with Services. Oslo: Fafo/AIS, http://www.fafo.no/ais/middeast/opt/opinionpolls/palestinian_opinions_2008/2008 -5 services.pdf

Fafo (2009): Surveying Palestinian Opinions, 2009. Oslo: Fafo/AIS.

Fafo (2010a): Surveying Palestinian Opinions 2010. Oslo: Fafo/AIS http://www.fafo.no /ais/middeast/opt/opinionpolls/poll2010.html

Fafo (2010b): Surveying Palestinian Opinions. Qualitative Interviews with Political Figures on the West Bank. Unpublished, 27 April, 2010.

Goldstein, E. B. (2009): Sensation and Perception. Wadsworth Publishing.

Halliday, F (2002): The Middle East in International Relations. Cambridge: Cambridge University Press.

Hancock, B. (1998, 2002): An introduction to qualitative research. Trent Focus for Research and Development.

Hooper, R. (1999): The International Politics of Donor Assistance to Palestinians in the West Bank and Gaza Strip (1993-1997). In Roy, S. (ed.): The Economics of Middle East Peace: A Reassassement. Middle East Economic Association, pp. 59-95.

IUED-PCBS (2005): Palestinian Public Perceptions IX (2006). Geneva: IUED, http://graduateinstitute.ch/palestine/pdf/PPPreportX_ch6.pdf

IUED-PCBS (2006): Palestinian Public Perceptions X. Chapter 6: Population Needs \& Assistance Delivered. Geneva: IUED, http://graduateinstitute.ch/palestine/pdf/PPPreportX_ch6.pdf

JMCC (2001): International and Local Aid during the second Intifada.I-II. An Analysis of Palestinian Public Opinion in The West Bank and The Gaza Strip. Jerusalem: JMCC-SDC, http://www.uclouvain.be/cps/ucl/doc/dvlp/documents/ReportI.pdf and http://www.uclouvain. be/cps/ucl/doc/dvlp/documents/ReportII.pdf

Karmi, G. (2005): With no Palestinian state in sight, aid becomes an adjunct to occupation. Guardian Unlimited 31 December 2005. 
1 Keating, M. et al. (eds) (2005): Aid, Diplomacy and Facts on the Ground. London: Chatam House. 2 Khadr, A. (1999): Donor Assistance. In Diwan, I. - Shaban, R. A. (eds): Development under Adversity: The Palestinian Economy under Transition. Washington: World Bank.

LeMore, A. (2008): Political Guilt, Wasted Money International Assistance to the Palestinians after Oslo. London: Routledge.

MAS (2005): Towards a More Effective Use of International Aid to the Palestinian People. Ramallah: Palestine Economic Policy Research Institute.

Meshal, K. (2006): We will not sell our people or principles for foreign aid. Guardian Online, 31 Jan., 2006. http://www.guardian.co.uk/world/2006/jan/31/comment. israelandthepalestinians (accessed July 2008).

Nakhleh, K. (2004): The Myth of Palestinian Development. Political Aid and Sustainable Deceit. Jerusalem: PASSIA.

OECD DAC (1997) DAC Guidelines on Conflict, Peace and Development Co-operation. A Policy Statement. Paris: OECD.

Paragi, B. (2010): Palestinian Perceptions on Foreign Aid. Qualitative interviews with Palestinian in the West Bank and Gaza Strip. Oslo: Fafo, unpublished.

Paragi, B. (2012): ..

Robbins, S. P. et al. (2009): Organizational Behaviour: Global and Southern African Perspectives. Maskew Miller Longman.

Said, N. (2005): Palestinian Perceptions of International Assistance. In Keating, M. et al. (eds): Aid, Diplomacy and Facts on the Ground. London: Chatam House, pp. 99-107.

Shamir, J. - Khatib, G. (2010): Palestinian and Israeli Public Opinion: The Public Imperative. Bloomington, IN: Indiana University Press.

20 Shearer, D. - Meyer, A. (2005): The Dilemma of Aid Under Occupation. In Keating, M. et al. (eds): Aid, Diplomacy and Facts on the Ground. London: Chatam House, pp. 165-176.

Volkart, E. H. (ed.) (1951): Social Behavior and Personality. Contribution of W. I. Thomas to Theory and Social Research. New York: Social Research Council.

World Bank (2000): Aid Effectiveness in the West Bank and Gaza. Washington: World Bank.

World Bank (2010): Net ODA Received Per Capita. http://data.worldbank.org/indicator/DT.ODA. ODAT.PC.ZS/countries/1W?display=grah (accessed October 4, 2010).

Zagha, A. - Jamal, M. (1997a): Foreign Aid and Development in Palestine, Vol. 1. Jerusalem: JMCC.

Zagha, A. - Jamal, M. (1997b): Mortgaging Self-reliance: Foreign Aid and Development in Palestine, Vol. 2. Jerusalem: JMCC.

Zhang, H. (2010a): 2010 West Bank Poll. Sample Design. Oslo: Fafo/AIS, http://www.fafo.no/ ais/middeast/opt/opinionpolls/palestinian_opinions_2010/West_Bank_sampling_2010.pdf

Zhang, H. (2010b): 2010 Gaza Poll. Sample Design. Oslo: Fafo/AIS, http://www.fafo.no/ ais/middeast/opt/opinionpolls/palestinian_opinions_2010/Gaza_sampling_2010.pdf 